\title{
Regional Development Dynamics and Decentralization in the Philippines: Ten Lessons from a 'Fast Starter'
}

Arsenio M Balisacan, University of the Philippines, Quezon City; and Southeast Asian Regional Center for Graduate Study and Research in Agriculture (SEARCA), Los Banos

Hal Hill, Australian National University, Canberra

Sharon Faye A Piza, Asia Pacific Policy Center, Quezon City

\begin{abstract}
Spatial disparities, regional dynamics and centre-region relations are the focus of much attention in the developing world, owing to growing analytical and policy interest, concern over deeply entrenched spatial inequality, transitions from economic crises or command economies, and the uneven effects of rapid global integration. Many countries are embarking on major decentralization programs. This paper examines regional dynamics and decentralization with reference to the Philippines, a country well suited to such a study and from which other developing countries can learn lessons. The Philippines initiated a major decentralization program relatively early (1991), and it is one of the most spatially diverse countries in the world. The reforms occurred in the wake of a deep economic crisis, and were accompanied by a major liberalization program.
\end{abstract}

Key words: Asia, The Philippines, decentralization, policy reform, regional development.

\section{Contact author:}

Professor Hal Hill

Division of Economics

Research School of Pacific and Asian Studies

The Australian National University

Canberra ACT 0200

Australia

Tel/fax: (61-2) 61253095/61253700

Email: hal.hill@anu.edu.au 


\section{Regional Development Dynamics and Decentralization in the Philippines: Ten Lessons from a 'Fast Starter'•}

\section{1) Introduction}

For several reasons - analytics, policy, deeply entrenched spatial inequality, transitions from economic crises or command economies, and the uneven effects of rapid global integration - spatial disparities and centre-region relations are the focus of much attention in the developing world. Regional science is now at the forefront of development issues. 'New economic geography has come of age', in the words of Neary (2001). Arguably, no author has done more to popularize the intellectual fusion of trade and geography than Paul Krugman. As he argued:

... one of the best ways to understand how the international economy works is to start by looking at what happens inside nations. If we want to understand differences in national growth rates, a good place to start is by examining differences in regional growth; if we want to understand international specialization, a good place to start is with local specialization (Krugman 1991: 3).

The motives for decentralization vary. There is pressure on central governments practically everywhere to devolve administrative authority and financial resources to the regions. Economic and political crises may trigger major (and sometimes hasty) decentralization programs, especially when authoritarian, centralized regimes crumble. Within the past two decades, for example, Indonesia, the Philippines and Russia have all experienced deep economic crises and far-reaching institutional and political change. Increased regional autonomy featured prominently in the democratic reform agenda of all three. Both Indonesia and the former USSR ceded territory in the wake of these crises.

Especially in large, spatially diverse countries, there is frequently disenchantment with rule from the centre. Local communities often regard capital cities as corrupt, authoritarian, arrogant and remote. Regional development concerns are also motivated by frustration with failed attempts to achieve progress in bypassed regions.

In some countries, increased regional autonomy may be an incidental consequence of the transition from plan to market. As governments dismantle a command economy and the size of the state enterprise sector shrinks, economic authority inevitably passes from central government planners to private economic agents. Hence power is decentralized, even in the absence

\footnotetext{
- This paper draws on a research project we have been coordinating on regional development and decentralization in the Philippines. We gratefully acknowledge the involvement of a team of researchers, whose work we have drawn on as indicated in the text, and the financial support of the Asian Development Bank Institute, Tokyo. The views expressed in the paper are those of the authors alone.
} 
of a formal decentralization program. China, Russia, Viet Nam and other former centrally planned economies illustrate this proposition.

In some cases, the experiments with decentralization are 'big bang' and hasty (for example, Russia and Indonesia, much of Latin America), while in others there is a long history of federalism and well-developed institutional structures governing centre-region relations (for example, India, Malaysia).

Although there are diverse and powerful pressures to shift power and resources out of the centre, there is no consensus in the literature on how far and how quickly decentralization ought to proceed. As Bird and Villaincourt (1998: 1) observe, 'Decentralization [is neither] a plague [n]or a panacea'. The general presumption is that policy competition between regions is desirable and that, beyond the obvious areas of central government responsibility, such as macroeconomic policy, law, foreign policy and defence, decision-making should be as close as possible to the stake-holders. For example, according to the fiscal federalism literature, with sufficient mobility of voters and capital, decentralization will provide a spur to efficient service delivery. It is also presumed that local governments are more likely than central governments to be responsive to community needs. It is therefore believed that competition for tax and service delivery will act as a discipline on bureaucratic excess and low-quality governance among regions. Mobile factors will exit jurisdictions that fail to deliver, so the argument goes. Nevertheless, the challenge for hypotheses generated by this literature is to explain why, in cross-country comparisons, there appears to be no discernible correlation between the degree of decentralization and economic growth (Martinez-Vazquez and McNab 2003).

Decentralization programs are frequently initiated as part of a regime change, involving both political democratization and economic liberalization. As countries open up to the global economy, subnational dynamics alter, sometimes profoundly. The regions best able to connect commercially to the global economy invariably grow more rapidly than the rest of the national economy, sometimes (as in coastal China) spectacularly so. Conversely, the problems in lagging and bypassed regions may become more serious. The latter scenario is more likely in cases of weakened central governments, unable to enforce firm rules governing centre-region relations, and lacking the fiscal capacity to invest in national infrastructure. In such cases, paradoxically, as international barriers to commerce decline, subnational barriers may actually rise, owing to inadequate infrastructure connecting coastal economies to the hinterland, and to the proliferation of internal barriers to trade in the face of weak governance.

The complexity and diversity of decentralization experiences therefore makes it difficult to provide general answers to a range of commonly asked questions on this topic. For example:

- What determines subnational patterns of development, and are these factors similar to those shaping inter-country differences?

- Are there general patterns of subnational inequality, of the type hypothesized by Williamson (1965)? 
- Are bypassed regions likely to become a serious national (and international) challenge as central governments retreat in authority and place less emphasis on interregional equity?

- As national boundaries become more porous and central governments less powerful, will coastal regions connect more to the global economy and less to their hinterland?

- What are some of the key issues and lessons in decentralization reforms?

- Is regional (subnational) competition likely to improve local-level (and therefore national) governance quality?

While the literatures on economic geography and fiscal federalism are highly relevant, many of these questions can be answered only with the aid of detailed country studies. These questions motivate this study, and we address several of them with reference to the Philippines.

The Philippines is ideally suited to a study of regional dynamics and decentralization. With a population nearing 90 million people, the country is highly diverse in terms of its geography, ecology, natural resource endowments, economy, ethnicity and culture (see Figure 1). Comprising 7,100 islands, it is the second largest archipelagic state in the world, after Indonesia. It is estimated to have 110 ethnic groups and 170 spoken languages.

(Figure 1 about here)

Economic activity is also highly uneven, and concentrated particularly in the national capital, Manila. Together with the two adjacent regions, it produces about 55\% of the country's GDP. Socioeconomic indicators also vary significantly across regions. The headcount poverty estimate for the two poorest regions is more than 10 times that of the national capital.

Moreover, policy makers have had to grapple with a number of complex region-specific challenges. The most durable of these has been the longrunning insurrection in the southern island of Mindanao. The islands stretching southwest from Mindanao are often alleged to be breeding grounds for international terrorist activity in Southeast Asia and beyond.

Whilst remaining a unitary state, the Philippines was one of the first countries in East Asia, and indeed in the developing world, to embark on a program of decentralization, in 1991. It did so in circumstance which are quite common in the developing world: regime collapse, deep economic crisis, and an attempt to reform political and institutional structures. That is, in the wake of the 20 year authoritarian rule of Ferdinand Marcos, a deep economic crisis resulted in the economy contracting by over $15 \%$ and, in a newly democratic era, there was a concerted push to devolve authority to the regions. ${ }^{1}$ The World Bank (2005) recently classified the country as a 'fast starter' in this respect, and one

\footnotetext{
${ }^{1}$ For a general review of Philippine economic development since the 1980s, see Balisacan and Hill (eds, 2003).
} 
with the 'strongest history of democratic decentralization' in East Asia. ${ }^{2}$ After a decade and a half, an evaluation of the analytical and policy issues of regional development and decentralization in the Philippines is timely, and has lessons for many other developing countries venturing down this path.

The country has other attractions for such a study. There is a more than adequate data base, and a reasonably developed and accessible literature. These include notably two 'benchmark' studies of regional development dynamics and centre-region relations, by Bahl and Miller (eds, 1983) and Pernia et al and Associates (1983), which provide a comprehensive picture of the late pre-decentralization era. There is also much public debate of the issue.

Our paper is organized as follows. In section 2 , to set the scene we provide a brief overview of Philippine regional history, policy and structures. Next in section 3 we examine regional development dynamics, focusing mainly on the post decentralization period, that is after the introduction of the Local Government Code in 1991. In section 4 we investigate centre-region relations and local governance in the country. We conclude with ten broad policy and analytical lessons from the country's experience.

\section{2) Regional Structures and Policies}

The Evolution of Regional Policy: The Philippines has evolved into a nation state since the time of the highly decentralized Spanish colonial era, in which the Catholic Church was as much a national institution as the Manila government (Corpuz, 1997). Since independence in 1946, Philippine policymakers have grappled with the issue of how to promote broad-based regional development in such a diverse setting, and what sort of centre-region structures are optimal. 'Regionalization' as a strategy to attain national development goals began to figure prominently in Philippine development thinking and planning in the 1960s. However, it was only in the 1970s that a full commitment to regional development emerged (Alonzo 1994). Pernia et al. (1983: 36-7) refer to the 1970s as the 'regional awareness period', pointing to several interrelated factors driving the central government's increased attention to the regions. These included the successful program to increase agricultural productivity as part of the green revolution; growing concern with urban congestion, especially around Manila, and related also to the centralizing bias of the import substitution regime; and serious insurgencies, mainly the disaffected Muslim community in the south and the communist New People's Army in several regions

In the late years of the Marcos regime, work began on a reformulation of centre-local relations. Serious research on the intricacies of centre-local relations, especially fiscal arrangements, had also commenced, resulting for

\footnotetext{
2 The Bank's East Asian 'fast starters' were the Philippines and Indonesia, in contrast to the 'incrementalists', China and Viet Nam, and 'cautious movers', Cambodia and Thailand (World Bank, 2005, 6-7). However, as will be argued below, the Philippine decentralization program was actually a good deal better prepared than that of Indonesia.
} 
example in a major study by Bahl and Miller (1983). The Local Government Code (LGC) which was eventually introduced in 1991 is actually similar to a draft prepared in 1983. The Bahl-Miller volume drew attention to the fact that, for all the rhetoric, the Philippines was a highly centralized state during this period, with the central government in effect delegating to the various local government units (LGUs). In fact, during the 1970s the share of local governments shrank sharply as the Marcos administration assumed ever more control. For example, the local government share of total public sector expenditure declined from $20.7 \%$ in 1969 to $10.3 \%$ in 1979 . The relative importance of their own-source revenue also declined. The reach of central government 'extended to day-to-day influence on fiscal decisions and administrative procedures' (Bahl and Schroeder 1983: 42). This centralization also greatly weakened the local government incentives for resource mobilization and efficiency.

Current Regional Structures: Following the collapse of the Marcos regime in early 1986, the 1987 Constitution was enacted. Article $X$ of the Constitution provides, within the context of a unitary state, for the territorial and political subdivision of the Philippines into provinces, cities, municipalities and villages, the latter known as barangays (see Figure 2). The formal second tier of government, comprising the LGUs and one region, the Autonomous Region of Muslim Mindanao (known as ARMM), consists of three layers, all democratically elected. These are provinces, municipalities and 'component cities', and the lowest tier, barangays, headed respectively by governors, mayors and captains. ${ }^{3}$ In addition, for central government administrative purposes, the country is divided into 17 administrative regions. These form a convenient basis for statistical presentation and analysis, but only one of them - the ARMM - has political authority.

\section{(Figure 2 about here)}

There has been continuing, though modest, fragmentation of administrative and political authority. In 1991, immediately before decentralization, there were 75 provinces, 60 cities, 1,543 municipalities and 41,820 barangays. ${ }^{4}$ As of 2003 , these numbers had expanded to $79,113,1,500$, and 41,971 respectively. The major change has therefore been a near doubling of cities, accompanied by a decline in the number of municipalities. This reflects in part the country's continuing high population growth and urbanization. The more generous fiscal treatment of cities, especially chartered cities, has also been a factor.

The LGC provides a comprehensive framework for centre-region relations. This included the transfer to LGUs of a wide range of functions and services, and divided responsibility for their provision among the various local tiers. It also specified a division of responsibility with regard to revenue assignment. This included the allocation of tax powers, including in some cases specified

\footnotetext{
${ }^{3}$ In addition there are 'independent cities', which are at the same level as provinces and which are directly divided into barangays.

4 The numbers had changed little from the late 1970s, when there were 75 provinces, 60 chartered cities and 1,484 municipalities (Bahl and Schroeder 1983a: 1).
} 
rates, together with revenue-sharing provisions among LGU tiers where relevant. The major tax reserved for LGUs was that on property. The central government retained authority for income tax (both personal and corporate), customs and excise duties, and the value-added tax. Additionally, the code specified an Internal Revenue Allotment (IRA), requiring that $40 \%$ of all internal revenue collections (calculated with a three-year lag) be allocated to local governments according to a formula based on land area, population and income.

\section{3) Regional Development Patterns ${ }^{5}$}

Patterns of Spatial Activity and Concentration: Manila dominates the Philippine economy, with the National Capital Region (NCR) generating a little over one-third of the country's GDP in recent years (Table 1). With the two regions surrounding it, Central Luzon and Southern Tagalog, this central zone produces about 55\% of the country's GDP. The island of Luzon, on which they are located, contributes almost two-thirds of the national economy, making it by far the largest of the three major island groupings. Luzon's economy has also grown marginally faster than the national economy since the 1970s, resulting in a gradual rise in its national share.

(Table 1 about here)

Manila is also by far the wealthiest region, with a per capita income about 2.75 times the national average (Table 2). This is more than double the income of the next richest region and 12 times that of the poorest. In fact, only two of the remaining 15 regions, both distinctive in nature, have per capita incomes above the national average. ${ }^{6}$ A third group of regions may be regarded as moderately well-off by national standards: those whose per capita income is below the national average of P52,470 in 2003 but above the ex-Manila national average of P38,600. They include a diverse group of regions: the two adjacent to Manila, Central and Western Visayas, and Southern and Central Mindanao. A fourth group comprises six poor regions: three in Luzon (Ilocos and Cagayan Valley in the north and Bicol in the south), Eastern Visayas, and two regions in the western part of Mindanao (Caraga and Western Mindanao). Finally, ARMM has to be grouped separately owing to its extremely low income - less than half that of the poor grouping, and less than one-quarter the national average.

(Table 2 about here)

\footnotetext{
5 The fragmentation of administrative boundaries complicates the task of regional development analysis over time. For the purposes of consistency, throughout this paper we use the 1997 classification, which groups the provinces into 16 regions, unless otherwise specified. Currently (that is, in 2006), the number of regions is 17, following the division of Region IV (Southern Tagalog) into two regions.

${ }^{6}$ These are the Cordillera Administrative Region (CAR) and Northern Mindanao.
} 
The last column of Table 2 shows average annual growth of regional GDP between 1985 and 2003. Most of the poor regions, including ARMM, grew more slowly than the national average of 3.1\%. At the other end of the range, the richest region, the NCR, grew at about the same pace as the national average. Figure 3 investigates the relationship between regional growth rates and (initial year) average incomes. The top right-hand quadrant (quadrant I) represents regions with above-average growth and income; quadrant II regions with below-average growth and above-average income; quadrant III regions with below-average growth and income; and quadrant IV regions with above-average growth and below-average income. In general the more heavily are quadrants II and IV populated, the more likely are regional differentials to be narrowing. In fact, the majority of regions are in the latter two quadrants: two in quadrant II and eight in quadrant IV, out of a total of 16. However, the clustering of regions close to the national growth average and the fact that the NCR and ARMM are such outliers caution against drawing too robust a conclusion.

(Figure 3 about here)

We formally test for the presence of convergence by estimating a standard regional growth equation, to determine whether incomes are converging to the mean over time. The evidence is mixed, and the results are sensitive to the selection of administrative boundaries. That is, the provincial data show convergence whereas the regional data do not. One plausible explanation for these mixed results is that a number of administrative regions contain groups of provinces with a wide range of per capita incomes.

Poverty and Social Indicators: Regional economic and social indicators generally correlate quite closely, although there are some deviations. Table 3 shows indicators of poverty, inequality, the human development index (HDI), life expectancy and literacy by region. For instance, regional mean income is highly correlated with poverty incidence (the Spearman correlation coefficient is 0.90), the $\mathrm{HDI}(0.96)$ and functional literacy (0.84). But it is weakly correlated with the Gini ratio (0.18) and primary enrolment (0.49). As expected, the correlation between the HDI and poverty is also high (0.96), but not that between the $\mathrm{HDI}$ and the Gini ratio (0.16).

\section{(Table 3 about here)}

The income and inequality data combine to generate the poverty estimates. The Philippines is a high-inequality country compared to most of Asia, with all but one of its regions (Central Luzon) registering a Gini ratio of at least 40. Income inequality is particularly high in most of the Visayas as well as Mindanao - ARMM being a notable exception - owing to the highly inequitable distribution of physical assets, particularly land, and to the mix of economic activities (mining, plantation agriculture) in these regions.

These high-inequality regions have, for example, land Gini ratios of close to $60 \%$, while the comparable figures for most of Luzon (excluding Bicol) are close to, or below, 50\%. As Balisacan (2003) has shown, it is the inequality within regions, not the inequality between regions, that accounts for over $80 \%$ of the national variation in household incomes. He further shows that high- 
inequality regions tend to have low steady-state growth rates compared to their lower-inequality counterparts. Moreover, his analysis of the data covering the past two decades indicates that changes in poverty incidence (as well as in other measures of income poverty) are attributable largely to changes in overall per capita income within regions, rather than to changes in income or asset inequality within or between regions.

The Special Case of Mindanao: Mindanao has special development challenges owing to the protracted conflict which has occurred there. ${ }^{7}$ For the period 1986-2004, 15 of the 21 Philippine provinces with the largest number of armed encounters over this period were in this region.

The protracted conflict in Mindanao has exacted a high price in at least three respects. The first has been the continuing high number of casualties: the annual fatality rate since 1986 has been at least 260 combatants, with a further civilian death toll of at least 85 persons. Typically, there are over 100,000 displaced persons at any point in time. Second, although it is virtually impossible to obtain an accurate monetary measure for the cost of the conflict, estimates range between P5 billion and P10 billion annually since 1975. These estimates follow the standard methodology of valuing human life only in terms of earnings potential. They do not take account of the many indirect economic and non-economic costs of conflict, or the general costs of warfare, dislocation and displacement, or the general costs to the nation (eg, foregone investment owing to the country's negative international image, and distraction for national policy-makers). Third, Mindanao's traditionally poor socioeconomic indicators have deteriorated still further relative to the rest of the nation, as highlighted in the above tables. The country's bottom 10 provinces have usually been dominated by conflict-affected regions. For example, the five provinces with the lowest life expectancy are all in Muslim Mindanao. People in the lower-ranked provinces have a life expectancy some 20 years below that in the richest provinces. Muslim Mindanao provinces also dominate the bottom end of the country's HDI rankings.

Population, Labour and Migration: Philippine demographics more or less reflect economic patterns. A little over half the nation's population lives in Luzon, whose share has been rising gradually since the 1970 s (Table 1). The remaining $45 \%$ of the population is fairly evenly divided between the Visayas and Mindanao. Within Luzon, Manila and the two surrounding regions dominate, with a gradually rising share in the range $35-40 \%$ of the population.

These patterns reflect the interplay of regional fertility differentials and migration. Historically, the major migration flows were into the national capital and surrounds and to the frontier regions, principally Mindanao (Pernia et al., 1983). Since 1980, the dominant migration stream has been into the two regions surrounding Manila, especially Southern Tagalog (Table 4). Only two other regions have (modest) net in-migration: the region of Central Visayas, with its capital the relatively prosperous second city of Cebu, and the resource-rich region of Northern Mindanao. Thus relative income differentials, together with employment and education opportunities, drive these patterns.

\footnotetext{
7 This sub-section draws heavily HDN and UNDP (2005), a report coordinated by the first author.
} 
In spite of decentralization, and the dismantling of the centralizing bias in favour of the capital region, it remains the dominant destination of migrant flows. ${ }^{8}$ In other words, migration continues to be, de facto, a key instrument of regional adjustment, including the well known phenomenon of migration out of poverty. Regional labour markets have also been liberalized gradually. The setting of minimum wages has been decentralized, and some regions, mainly poorer ones, are beginning to compete for employment by offering more flexible labour market regulations (Sicat 2003).

(Table 4 about here)

Infrastructure and Integration: Infrastructure is the glue that unifies the national economy, and it is in many respects the single most important instrument of regional policy. It enables people and goods to move quickly and efficiently around a country. The composition of this infrastructure also matters. For example, efficient connections to the global economy alongside the poorer provision of domestic networks - an increasingly accurate characterization of the situation in the Philippines - will result in a series of internationally oriented enclaves of economic activity weakly integrated to the hinterland.

Effective infrastructure provision requires competent governance. First, many infrastructure projects entail long gestation periods, and therefore have particular financing and policy predictability requirements. Second, a number of sectors have 'natural monopoly' characteristics (for example, power generation, land-line telecommunications, major trunk roads, international airports), which in turn prescribe a role for government as regulator, though not necessarily provider. Third, following a decentralization program, there will be many players in the industry, including several tiers of government, the state-owned providers and some foreign firms, as well as a number of regulatory agencies. There are therefore major coordination issues.

Philippine infrastructure indicators generally follow per capita income rankings, with the better-off regions having the capacity (and political influence) to fund better-quality physical facilities. This is illustrated in the standard indicators of road density, access to water, electricity and irrigation, and telephone density (Table 5). Manila and its two surrounding regions clearly register above-average physical infrastructure indicators in most respects. Outside this central region, the picture is more variable. One notable feature is that Mindanao does not emerge as a notably infrastructure-deficient region by Philippine standards, reflecting the region's high priority status both with the government and the donor community.

(Table 5 about here)

The Philippine infrastructure report card is deficient in key respects (Llanto, 2006), and this appears to be holding back the process of efficient regional

8 This region is also the major source of the estimated 8 million Filipinos residing abroad. Their remittances, estimated to be equivalent to almost $50 \%$ of merchandise exports, are the third largest in the developing world (Burgess and Haksar, 2005). 
economic integration. In a recent Global Competitiveness Report, the country's infrastructure performance was ranked 89th out of 102 countries. The country is underinvesting in infrastructure: its infrastructure investment to GDP ratio is about half the East Asian average.

There are three interrelated problems. First, the country has chronic fiscal constraints, as a result of past fiscal crises and the continuing poor revenue performance of the national government. Fiscal constraints have a particularly adverse effect on infrastructure, since invariably capital works are the first to be cut in budget-pruning exercises. ${ }^{9}$ Second, the overall regulatory framework lacks cohesion, coordination between national agencies and between the various tiers of government, and a clear division of responsibilities. About 30 national agencies are involved in infrastructure decision-making. Third, national-level decision-makers appear unable or unwilling to deliver the longterm policy predictability and guarantees that major private (and especially foreign) providers require, resulting in potential suppliers factoring in very large risk premia. The corruption and political patronage associated with the award of large infrastructure projects is a feature of many countries. But the politicization of large infrastructure investments appears to be unusually severe in the Philippines, with several key projects over the past decade remaining incomplete.

The picture varies considerably by subsector. There have been some positive achievements. For example, domestic shipping, civil aviation and cellular telecommunications services were effectively deregulated during the 1990s. ${ }^{10}$ Roads are perhaps the weakest link, and here coordination failures are serious. The two major national agencies with responsibilities for roads, the Department of Public Works and Highways and the Toll Regulatory Board, do not coordinate their activities effectively. There also appears to be a 'missing middle' in the road network. The national government assumes responsibility for the major trunk network. While local governments have limited infrastructure budgets, ${ }^{11}$ they are responsive to local constituencies demanding farm to market roads. Reflecting the division of political power, secondary roads connecting the national and local road networks suffer from continued neglect and constitute the major weak link.

Is the Philippines becoming a more spatially integrated economy over time? In Figure 4, we test for this by presenting estimates of coefficients of variation for provincial prices during $1985-2003 .{ }^{12}$ Two sets of price indices are shown,

\footnotetext{
${ }^{9}$ As a corollary, there is a tendency to rely on donor agencies to supply infrastructure, resulting in an investment strategy that is short term in orientation and poorly integrated.

${ }_{10}$ In the case of telecommunications, for example, Salazar's (2006) comparative study shows that the Philippines moved more quickly than several of its neighbours, particularly Malaysia.

${ }^{11}$ Moreover, while the expenditure of local governments as a percentage of GDP has doubled since decentralization, their infrastructure budgets have not expanded commensurately.

12 Available regional price indices for the 1980s and beyond are strictly not comparable owing to the marked changes in the composition of regions over
} 
one consisting of a basket of food and non-food items ('all commodities') and the other consisting of food items only. ${ }^{13}$ Ideally, the spatial comparison should involve only tradable goods. Arguably, food is highly tradable, hence the latter price index can be regarded as a reasonable measure for regional price comparison of tradable goods. As Figure 4 shows, the two indices exhibit the same pattern: the coefficients of variation tend to rise in the second half of the 1980s through early 2000s, suggesting that impulses for domestic integration have been muted by widening regional price variations in recent years. This pattern is an outcome partly of evolving disparities in infrastructure development and institutional arrangements, and partly of deregulatory reforms in transport and related services.

(Figure 4 about here)

Regional Dynamics: Global and Regional Interactions: As emphasized above, the Philippines embarked on both trade liberalization and decentralization, more or less simultaneously. It might be hypothesized that the dismantling of trade barriers would remove the centralizing regulatory biases embedded in four decades of import substitution, allowing footloose activities to migrate to the most economic locations, perhaps shaping a new economic geography. However, the results have been mixed. There has been some deconcentration, in the sense of movement out of Manila. However, the overwhelming beneficiaries have been just three regions: the two Manila spillovers of Southern Tagalog and Central Luzon and the Cebu-centred Central Visayas. Export growth from these regions has been rapid, with Southern Tagalog's share of the total rising from 4\% to $51 \%$ in the 10 years from 1993 to 2003. Moreover, there has been a reconcentration of exports towards Luzon, with its share rising from $77 \%$ to $90 \%$ over this period. Luzon's share of manufacturing output and employment is similarly dominant, and rising. Thus on balance trade liberalization has not led to any reduction in industrial concentration. Indeed, depending on how it is measured, spatial concentration may actually have increased.

The specific form of the liberalization measures explains these trends. Exports have been the major source of dynamism, and they have emanated overwhelmingly from the concessional facilities offered by the government, mainly under the auspices of the Philippine Export Zone Authority, PEZA. As well as offering fiscal and regulatory incentives, the zones have been selected on the basis of their connections to international infrastructure, principally airports and ports. Hence, the availability of infrastructure and the location of export zones have become the new drivers of industrial location. Furthermore, owing to the partial nature of the trade reforms and the resultant 'enclave' characteristic of these zones, the process of backward linkage formation, spatially and across size groups, has been inhibited (Tecson, 2006). A similar pattern of location appears to be evident in the new export-oriented service activities, such as call centres and medical services. Here too there is an emerging concentration in and around the capital region. It is likely that

time. Moreover, the available data do not capture price variation across regions, since each region has a price index value of 100 for the base year. 13 Details of the construction of the price indices are shown in Balisacan (2001). 
different forms of infrastructure matter: principally telecommunications and, because export-oriented service activities rely more on person-to-person contacts, international airports. Of crucial importance is the availability of an educated and cosmopolitan workforce, whereas serviced industrial estates and ease of customs movements are less relevant. In all these respects Manila and surrounds have a major competitive advantage over more distant regions.

\section{4) Centre-Region Relations and Local Governance}

Centre-region relations: ${ }^{14}$ The Philippine decentralization program assigned functions to the various tiers of government broadly consistent with public finance notions that power should rest with the jurisdiction best able to internalize the benefits and costs associated with the provision of services. The principal exception has been education, which for political reasons was retained by the central government.

As a result of decentralization, LGU expenditure as a share of GDP approximately doubled, but the amounts remained relatively small, rising from $1.6 \%$ of GDP in 1985-91, prior to the introduction of the Local Government Code, to $3.3 \%$ in 1992-2003. The Philippines is thus only a moderately decentralized state. For example, the (unweighted) share of subnational expenditures in the total public sector for six East Asian countries was 33\% in 2001-02, whereas the share for the Philippines was $26 \%{ }^{15}$ Similarly, the share of LGUs in total government expenditure (net of debt service) rose from an average of $11 \%$ before the introduction of the code to $21.2 \%$ afterwards. As one would expect, LGU expenditures generally rose in the sectors for which they had assumed responsibility, although in social welfare and infrastructure the increases were minimal.

With regard to the clarity of expenditure assignment, Manasan (2006) concludes that the arrangements are clear enough in principle, but in practice have been subverted by loopholes that permit arbitrary intervention by central government departments and members of Congress. The central government has also continued to pass on unfunded mandates to the LGUs, thus violating the public finance principle that 'finance follows function'.

The allocation of tax assignment is also broadly consistent with public finance criteria related to efficiency, equity and administrative feasibility, with LGUs in particular having responsibility for tax bases on factors that have low interjurisdictional mobility (for example, property tax and community tax). However, the arrangements score less well with regard to the autonomy criterion. Apart from property tax, the LGU tax base remains small, the only other revenue sources being business taxes, fees and user charges, and poll taxes. The central government continues to control the major productive tax bases, including personal and corporate income tax, value-added and excise tax, and customs duties. Moreover, LGUs have limited authority to change

\footnotetext{
14 This subsection draws in part on Manasan (2006) and Manasan and Chatterjee (2003).

15 The shares were: Cambodia, 17\%; the PRC, 69\%; Indonesia, 32\%; Philippines, 26\%; Thailand, 10\%; and Viet Nam, 48\% (World Bank 2005: 10).
} 
and set the rates: the LGC sets limits (floors and ceilings) on tax rates imposed by LGUs; these may be adjusted only every five years; and they may be adjusted by no more than $10 \%$.

Thus, there are serious misalignments of revenue assignments and expenditure responsibilities, both between the centre and the regions and among regions. Many of these problems were identified long ago by Bahl and Miller (1983), and it is puzzling that they remain unaddressed after decentralization. As a result of this misalignment, there is a growing imbalance between the revenue and expenditure responsibilities of LGUs. Comparing the pre- and post-code periods identified above, the share of LGUs in total government revenue rose from $4.9 \%$ to $6.9 \%$, while their expenditure rose much more quickly, from $11 \%$ to $22.9 \%$. As a result LGUs have become increasingly dependent on central government transfers, which, as a share of LGU income net of borrowings, rose from 38\% 1985-91 to 65\% 1992-2003.

Central government transfers to the regions come in two forms: formuladriven block grants known as the Internal Revenue Allotment (IRA), and ad hoc categorical grants. They are supplemented by the various and sharply rising congressional 'pork-barrel' schemes. The IRA includes a formula for the division of funds among the various LGU tiers, based on population, land area and equity. Although in principle formula-driven and automatic, in practice, as Manasan (2006) observes, the IRA has emerged as a 'highly unpredictable' source of funding, owing to frequent changes in magnitude and composition. This is especially so during periods of fiscal crisis, when the central government has employed a variety of measures to delay or reduce payments.

With regard to horizontal balance, Manasan (2006) found per capita IRA to be positively related to per capita household income over the period 1995-99. That is, contrary to the intent (and spirit) of the LGC, the issue of horizontal equity is not being addressed. However, perhaps surprisingly, the smaller categorical grants are occasionally fiscally equalizing, as, for example, during the period 1998-2000.

The proliferation of LGU 'nuisance taxes' has become a serious problem, with very little attempt to clean them up since 1992. A large number of taxes, fees and user charges generate less than $0.1 \%$ of total LGU revenue. There is also great complexity regarding the type and level of fees, which directly contributes to widespread undercollection. ${ }^{16}$ For example, in the case of property tax, the failure of many LGUs to carry out a general revision of assessment, mandated to occur every three years, has become a major problem. $^{17}$

${ }^{16}$ For example, the World Bank and ADB (2005: 21) notes that, in the city of Bacolod, 'there are over 200 different rates for the mayor's business permit fee, as rates vary by the type of establishment. Similarly, there are 24 fees for amusement places ...'.

17 In the words of the World Bank and ADB (2005: 22): 'Most LGUs [visited] have not undertaken a GRA [general revision of assessment] since 1991'. 
Local Institutions and Governance Quality: It would be a mistake to blame all the ills on the centre. LGUs have generally been unwilling to raise their own revenue, even through potentially rich sources such as property tax. As noted, the share of the IRA in total LGU income net of borrowing has been rising substantially. Thus the IRA has effectively substituted for own-source revenue generation. The widespread perception is that LGUs are invariably controlled by local elites who are unwilling to tax themselves, a point emphasized earlier by Bahl and Miller (1983). In addition, LGUs have generally been unable or unwilling to enact major fiscal reforms. Their financial records are poorly maintained and audited, and lack transparency. ${ }^{18}$ Moreover, local governments continue to employ a significant proportion of 'non-career' staff, an a priori indicator that normal recruitment procedures have been bypassed. ${ }^{19}$

This in turn begs the wider question of whether the decentralization program has delivered better-quality governance, including a 'reform dividend' for the better-governed regions. It needs to be emphasized that, more than is the case for national governance, it is no simple matter to measure local governance quality. Although the HDI is often used as a proxy for local governance quality, it is inadequate for this purpose in that it only captures outcomes, unlike variables such as transparency and participation. Research is continuing on a range of other governance measures.

Complicating the evaluation of LGU performance is that there are no obvious socio-economic correlates of reported high governance quality. For example, one of the richest and one of the poorest cities (Makati and Naga respectively) are widely regarded as being among the best governed. Nor is the evidence of 'positive neighbourhood effects' compelling; that is, well and poorly governed LGUs are frequently contiguous, even allowing for the possibility of lagged demonstration effects. Employing growth empiric techniques, for example, Mapa (2006) shows that there are no discernible neighbourhood effects on provincial income growth in the Philippines. ${ }^{20}$

There is a range of practical obstacles to the effective operation of a framework under which competition across regions delivers improved governance and higher growth. For one thing, standards of governance may be endogenous to the growth process, in the sense that the standards may be poor because the level of development is low. Moreover, local government elections in the Philippines have generally not been an effective instrument for exacting accountability. That is, success in the political arena is only weakly correlated with development achievements. There are several explanations for the latter outcome. One is the lag between improved governance and faster development. These lags may go beyond the local electoral cycle of

18 In the most recent audit, for the year 2000, only 250 of the 1,689 LGUs were given clean audit reports by the Commission on Audit (World Bank and ADB 2005: 39).

${ }^{19}$ In 2001, 38.6\% of local government staff were non-career, compared to just 4.7\% for the central government (World Bank 2005: 136).

${ }^{20}$ As an illustration, within Manila, Makati City, hosting the nation's premier business district, is generally regarded as well governed. Yet neighbouring Pasay City to its south registers poorly according to the usual indicators. 
three years, rendering investments in development (for example, health and education) politically unattractive as compared to short-term, quick-gestation projects. LGUs in any case have only limited control over policy levers compared with the national government. Also, the country's electoral laws and processes provide no guarantee that the electorate's preferences will be reflected in policy. Moreover, analyses of governance in the Philippines, however refined, have to take account of the fact that politics remains highly personalistic, indeed 'dynastic', especially at the local level, and thus formal definitions of governance quality will not necessarily be reflected in electoral performance. ${ }^{21}$

Furthermore, the central government has not been able to supply some of the key ingredients of an effectively functioning federal framework. These include a competent legal system and police service (the latter was not returned to local governments with decentralization), a stable macroeconomic policy framework and a predictable, transparent structure of local government grants that rewards local initiative.

The evidence on the quality of LGU service provision since decentralization is mixed. The World Bank (2005) comparative report detects no overall deterioration in the services provided by local governments. Although the proportion of LGU budgets devoted to infrastructure has declined, the LGU share of this sector is small. It also notes that regional differences in infant mortality rates have declined, but it is not clear that decentralization has been the key determining factor in this. In fact, as Lieberman, Capuno and Minh (2005) observe, some local health facilities in the Philippines have deteriorated to the point where patients resort to services in the private sector, or to those offered by higher-level government tiers. International comparisons of local education performance in the Philippines are limited by the fact that, contrary to usual practice, education was not decentralized in the Philippines.

Unfortunately, a particular disappointment has been the governance record in ARMM. The general security situation has of course complicated the decentralization process there. But in addition, elections in ARMM since 1990 have been marred by fraud and violence, financial mismanagement has been common, and the local bureaucracy is bloated and ineffective.

Thus, the record has been mixed, and has to be understood in the context of a central government not able to deliver the key ingredients of success. Transforming institutions, structures, processes and (especially) mindsets is a slow, long-term process. The transfer of around 70,000 personnel from the central government to the regions has commenced but remains incomplete. Yet the accountability mechanism of 'voice' is beginning to have an impact. Gradually, competition between the regions is increasing. The annual Galing Pook awards, which recognize local government excellence and innovation, are taken seriously. In the regions, citizens perceive more clearly the sources

${ }^{21}$ For example, Coronel et al (2004) show that, over the period 1987-2004, two-thirds of congressional representatives had relatives simultaneously serving in other elective positions. More than half of the latter were governors or mayors. 
of poor decision-making in public service delivery, and local-level accountability is generally on the rise. Activist, high-quality LGUs can make a difference. ${ }^{22}$ In addition, in the more internationally connected regions, there is some evidence that the imperative of global competition is gradually lifting standards of governance. Whether 'exit' is having an impact remains unclear. As we have seen, interregional migration in the Philippines is extensive, although the principal explanatory factor appears to be relative income levels, that is migrants selecting richer regions rather than necessarily bettergoverned ones.

\section{5) Conclusions and Lessons}

We conclude by highlighting a number of key analytical and policy lessons, many of broader relevance to other developing countries undertaking decentralization programs. At least 10 warrant attention. We group them under two broad themes: regional development dynamics and the decentralization program.

\section{$\underline{\text { Regional Development Dynamics }}$}

First, trends in the global economy have shaped the economic geography of an increasingly open Philippine economy. The regions which are better connected to the global economy can be expected to grow more rapidly. The international evidence on this is very powerful, from China's coastal regions to Mexico's border with the United States. In the Philippine case, this notion has to be modified in two respects. First, there is no single region that can be identified as the most globally connected. Rather, there are a number of enclaves with better global connections. These include principally the capital, Manila, and its surrounding corridors, the second city, Cebu, and some second tier regions such as the former US naval base of Subic Bay, and Cagayan de Oro in Mindanao. The second modification relates to the effect of international migration and remittances. Remittances are now so large that they need to be incorporated into analysis of international impacts on subnational economic geography. These overseas migrant workers are drawn disproportionately from better-off regions and households in the Philippines. Hence, these two impacts from the global economy are almost certainly increasing regional inequality in the country.

Second, the Philippines is significantly underinvesting in infrastructure, owing to continual fiscal crises and an unattractive commercial climate for long-term private investors. This not only slows growth, but also limits the formation of linkages between the internationally oriented segments of the economy and the rest of the countryside. Moreover, the allocation of scarce infrastructure

22 Quezon City, the largest of Metro Manila's cities, is a case in point. The mayor who took office in 2001 inherited a large deficit. Through a determined revenue collection program he increased income by over $50 \%$ in one year, and his government was able to record a surplus by the end of 2002. The initiatives he embraced included a range of carrot-and-stick measures, including prosecution of delinquent tax-payers, inducements for prompt payment, more efficient collection procedures and an overhaul of staff performance. See World Bank (2005: 123, Box 6.2). 
funds has had implications for regional development patterns. Following the dismantling of the old import substitution regime, the new driver of spatial development patterns has been the location decisions of export zones. In this context, the Philippine government (and donors) has been more inclined to invest in internationally oriented infrastructure (ports, harbours and associated facilities) than in domestic transport networks and corridors. The effect has been to reinforce the internationally connected enclaves at the expense of a denser set of domestic connections, a factor exacerbated by the regulatory barriers erected between firms inside and outside the export zones.

Third, there have been no major changes in the ranking of Philippine regions by socioeconomic indicators over the past two decades. The regions with above-average indicators continue to be Manila and its surrounds, while the relatively poorer regions remain so, especially those in the conflict-affected regions of Mindanao. This reflects both the generally slow rate of economic growth nationally - rankings are more likely to change with faster growth and the absence of any major change in national policy settings, notwithstanding the decision to decentralize. ${ }^{23}$

\section{The Decentralization Program}

Fourth, decentralization in the Philippines has been neither a notable success nor a disappointing failure. The reform has not delivered what some of its proponents may have expected: a decisive shift of power and resources away from the centre; a vibrant, efficient and responsive system of local government; and a general lift in the quality of governance through the competitive 'voice' and 'exit' accountability mechanisms. Conversely, the reform could hardly be termed a failure. It has broadly 'worked' in the sense that some administrative and political authority has been transferred to the regions, and some local governments have performed well. A key conclusion from the literature is that a decentralized system of government is able to function effectively only if the central government plays its part in delivering good-quality national governance, sound fiscal policy and rapid economic development. In all three respects, the contribution of successive Philippine national governments has been deficient.

Fifth, while the Philippine decentralization program was carefully prepared, well documented and generally based on sound principles, the record of implementation has been mixed. At a general level, the division of responsibilities between the central and local governments is clear, the assignment of functions across jurisdictions follows public finance principles, and there is reasonable clarity of expenditure assignment.

In practice, the current arrangements have not devolved efficiently and cleanly to local governments. The division of responsibilities remains ambiguous. The central government continues to intervene arbitrarily in what are considered local government responsibilities, including the transfer of unfunded mandates. A decade and a half on, it has yet to transfer all of the staff that

${ }^{23}$ One caveat to this conclusion is that the rankings exhibit greater fluidity if regions are measured at a more disaggregated (provincial or municipality) level rather than at the regional level. 
were supposed to be relocated to LGUs. The IRA has not constituted a predictable revenue stream, owing to frequent and arbitrary central government and congressional interference. As a result of these unstable funding arrangements, LGU revenue-raising efforts have been disappointing, a problem compounded by the reluctance of local elites to tax themselves. In consequence LGUs have become more, not less, dependent on central government transfers.

Sixth, the record has also been mixed with regard to vertical and horizontal balance between the central and local governments, and among local governments. The LGUs remain relatively small actors in the Philippine economy, their expenditure amounting to just 3.3\% of GDP in the postdecentralization era, much less than in most decentralized regimes. There is a growing vertical imbalance between LGU revenues and LGU expenditures: that is, the LGUs' share of total public sector expenditure is more than three times their share of total public sector revenue. Moreover, IRA allocations do not appear to be consistent with the objective of horizontal equity, although outcomes vary across regions depending on the composition and magnitude of ad hoc categorical grants.

Seventh, coordination between and among the different tiers of government continues to be inadequate. An effectively functioning centre-regional governance partnership requires a clear division of responsibilities, adequate funding and bureaucratic capacity at both levels. Here also the current Philippine arrangements are deficient. There is a 'missing middle' in the provision of a range of services, such as roads. In sectors such as agriculture, where large externalities are present (in R\&D, extension, infrastructure and environmental management), either a central government presence or effective coordination mechanisms among local governments (or most likely both) are required. There are also pronounced funding discrepancies among LGUs. Under the funding arrangements, provincial governors are starved of resources, whereas city mayors have much stronger funding bases, especially in better-off regions. As a result, there is tremendous political pressure for municipalities to circumvent population requirements and be reclassified as cities.

Eighth, notwithstanding measurement difficulties, there is considerable variation in governance quality across local governments. What remains unclear is whether one can identify the structural determinants of these differences, or whether instances of high-quality governance are 'accidents of history' driven by the strongly personalistic nature of Philippine politics, both nationally and locally. There are instances of emulation and replication, particularly in contiguous regions. But one would hesitate to argue that the ideal of 'competitive regionalism' has become a feature of Philippine local government, in the sense that better-governed regions are consistently rewarded with a reform dividend of in-migration of mobile factors, especially investment and skilled labour.

Ninth, decentralization has evidently had little impact on the country's deeprooted conflict in Mindanao. The insurgency continues unabated, and socioeconomic indicators in ARMM have worsened relative to the rest of the nation. Governance in this autonomous region has been very weak, including 
its record on education. ${ }^{24}$ Of course, the primary responsibility for resolving the conflict lies with the central government, and regional disaffection has many dimensions, national and local, economic and political. A relatively modest decentralization program could hardly be expected to resolve such a complex problem. Nevertheless, even at the margin its contribution has been minimal.

Tenth, our study draws attention to the need for both a common, nationwide policy agenda and a set of region-specific goals. On the national agenda should be policies to accelerate national growth and significantly increase public and private investment in physical infrastructure and human capital. There also needs to be at least a 'minimalist' set of nationwide social objectives relating to education and health. But regional policy also draws attention to diversity, and to the fact that a common policy template cannot be applied to all regions. For example, our discussion of Mindanao drew attention to the fact that the resolution of conflict is the most pressing goal. Mindanao's infrastructure, in contrast, is relatively good, reflecting the attention the region has received from the central government and donors. Elsewhere, the mix of required policy interventions differs. For regions characterized by long-term poverty, infrastructure investment and attention to local economic opportunities will likely be the key, alongside national minimum needs and poverty-targeting programs (though focused on individuals and households more than on regions). Labour market reform has played a role in enabling poorer regions to attract labour-intensive activities, with subcontracting networks connecting them to major urban centres potentially important, if infrastructure can be improved.

\section{References}

Alonzo, R.P. (1994), 'A Review of Equity-oriented Investment Criteria and the Medium-term Public Investment Program', pp. 185-231 in P.S. Intal, Jr and M.C.S. Bantilan (eds), Understanding Poverty and Inequality in the Philippines, National Economic Development Authority, Manila.

Bahl, R. and B.D. Miller (eds) (1983), Local Government Finance in the Third World: A Case Study of the Philippines, Praeger, New York.

Bahl, R. and L. Schroeder (1983), 'Local Government Structure, Financial Management, and Fiscal Conditions', pp. 1-45 in Bahl and Miller (eds).

Balisacan, A.M. (2001), 'Rural Development in the 21st Century: Monitoring and Assessing Performance in Rural Poverty Reduction', in D.B. Canlas and S. Fujisaki (eds), The Philippine Economy: Alternatives for the 21st Century, University of the Philippines Press, Quezon City.

Balisacan, A.M. (2003), 'Poverty and Inequality', pp. 311-41 in Balisacan and Hill (eds).

${ }^{24}$ Recall that ARMM is the only LGU in the Philippines that has responsibility for education. 
Balisacan, A.M. and H. Hill (eds) (2003), The Philippine Economy: Development, Policies and Challenges, Oxford University Press, New York.

Bird R. and F. Villaincourt (eds) (1998), Fiscal Decentralization in Developing Countries, Cambridge University Press, Cambridge.

Burgess, R. and V. Haksar (2005), 'Migration and Foreign Remittances in the Philippines', IMF Working Paper, WP/05/111, Washington DC.

Coronel, S., Y. Chua, L. Rimban, and B. Cruz (2004), The Rulemakers: How the Wealthy and the Well-born Dominate Congress, Philippine Center for Investigative Journalism, Quezon City.

Corpuz, O.D. (1997), An Economic History of the Philippines, University of the Philippines Press, Quezon City.

HDN and UNDP (Human Development Network and United Nations Development Program) (2005), Philippine Human Development Report: Peace, Human Security and Human Development in the Philippines, Manila.

Krugman, P. (1991), Geography and Trade, MIT Press, Cambridge MA.

Llanto, G.M. (2006), 'Infrastructure and Regional Growth in the Philippines', Philippine Institute for Development Studies, Makati.

Lieberman, S. J.J. Capuno and H.V. Minh (2005), 'Decentralizing Health: Lessons from Indonesia, The Philippines and Vietnam', pp. 179-208 in World Bank (2005).

Manasan, R.G. (2006), 'Decentralization and the Financing of Regional Development in the Philippines', Philippine Institute for Development Studies, Makati.

Manasan, R.G. and S. Chatterjee (2003), 'Regional Development', pp. 342380, in Balisacan and Hill (eds).

Mapa, D.S. (2006), 'Young Population Matters - More Is Not Necessarily Merrier: A Study on the Determinants of Income Growth in the Philippines', Asia-Pacific Policy Center, Quezon City.

Martinez-Vazquez, J. and R.M. McNab (2003), 'Fiscal Decentralization and Economic Growth', World Development, 31(9): 1,597-616.

Neary, J.P. (2001), 'Of Hype and Hyperbola: Introducing the New Economic Geography', Journal of Economic Literature, 39(2): 536-61.

Pernia, E.M., C.W. Paderanga, Jr, V.P. Hermoso and Associates (1983), The Spatial and Urban Dimensions of Development in the Philippines, Philippine Institute for Development Studies, Manila.

Salazar, L. (2006), Getting a Dial Tone: Telecommunications Liberalization in Malaysia and the Philippines, Institute of Southeast Asian Studies, Singapore. 
Sicat, G.P. (2003), Economics, New Edition, Volume 3: Philippine Economic and Development Issues, Anvil, Manila.

Tecson, G. (2006), 'High-Tech Industry Development in the Philippines: At a Dangerous Crossroad?', pp. 225-258 in Y.P. Chu and H. Hill (eds), The East Asian High-Tech Drive, Edward Elgar, Cheltenham.

Williamson, J.G. (1965), 'Regional Inequality and the Process of National Development: A Description of the Pattern', Economic Development and Cultural Change, 13(4): 13-45.

World Bank (2005), East Asia Decentralizes: Making Local Government Work, Washington DC.

World Bank and ADB (Asian Development Bank) (2005), Decentralization in the Philippines: Strengthening Local Government Financing and Resource Management in he Short Term, Washington DC and Manila.

Figure 1

The Philippine Regions, 2003

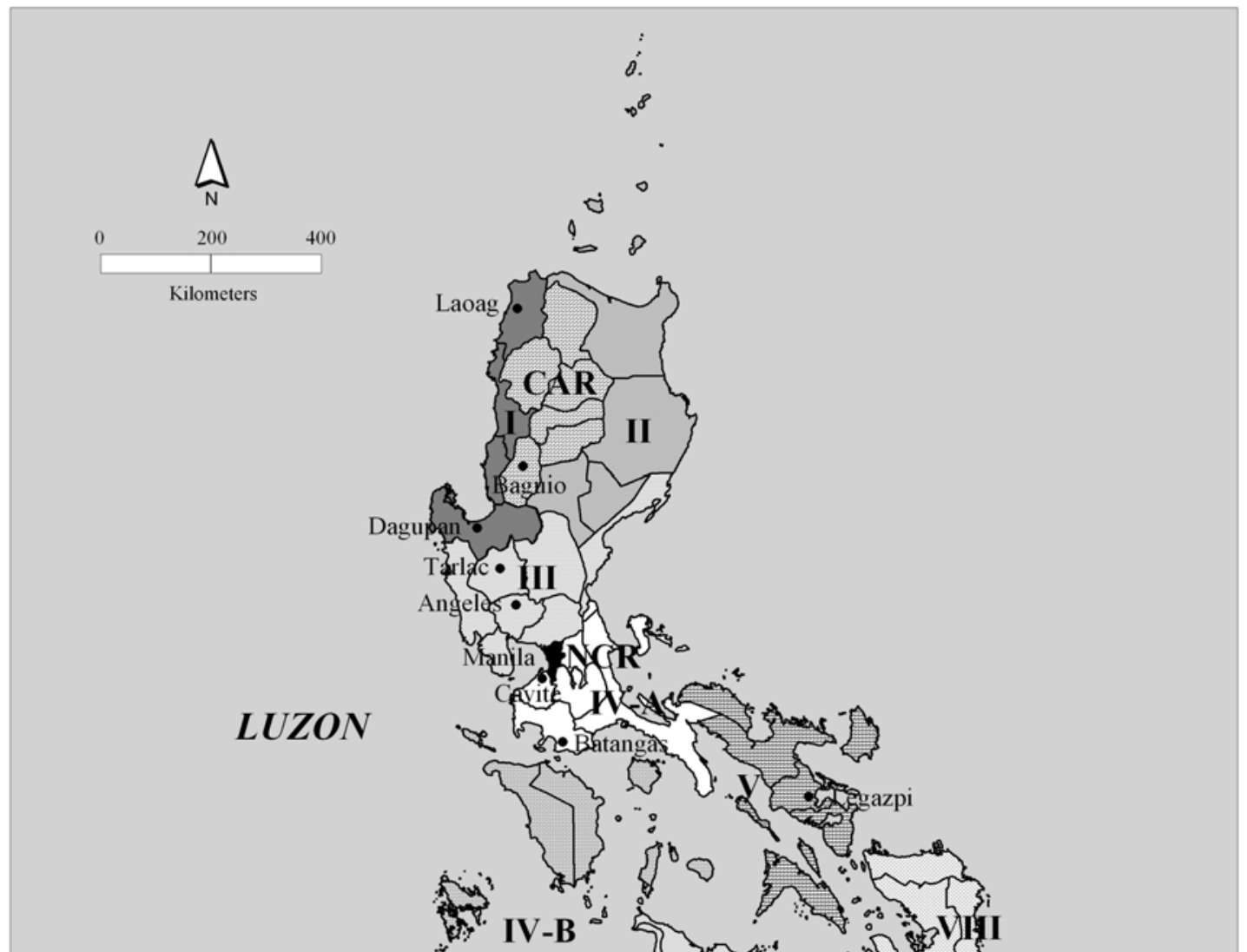


Figure 2

Local Government Structure, 2003

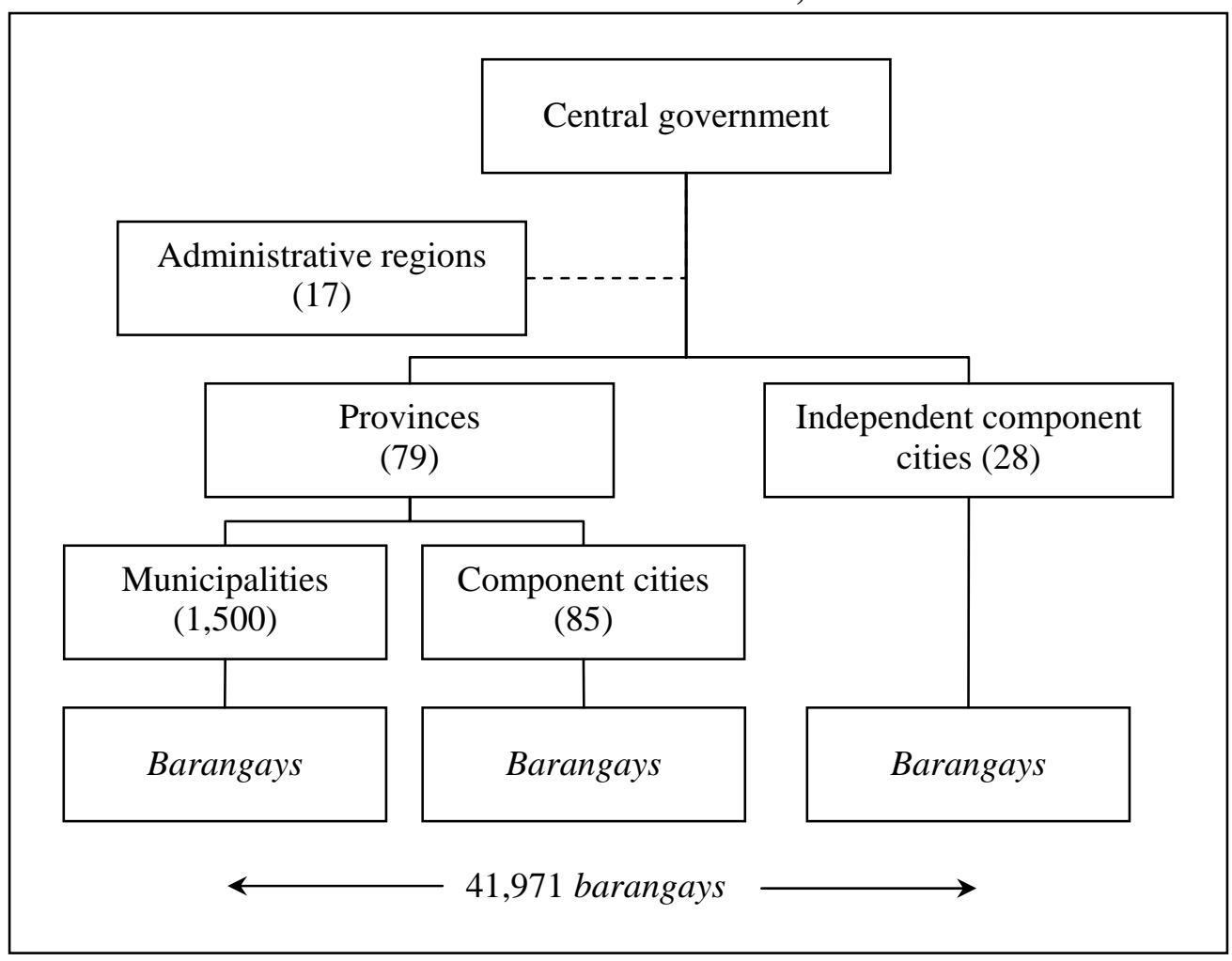

Source: Department of Interior and Local Government 
Figure 3

Regional Growth versus Initial Regional Income

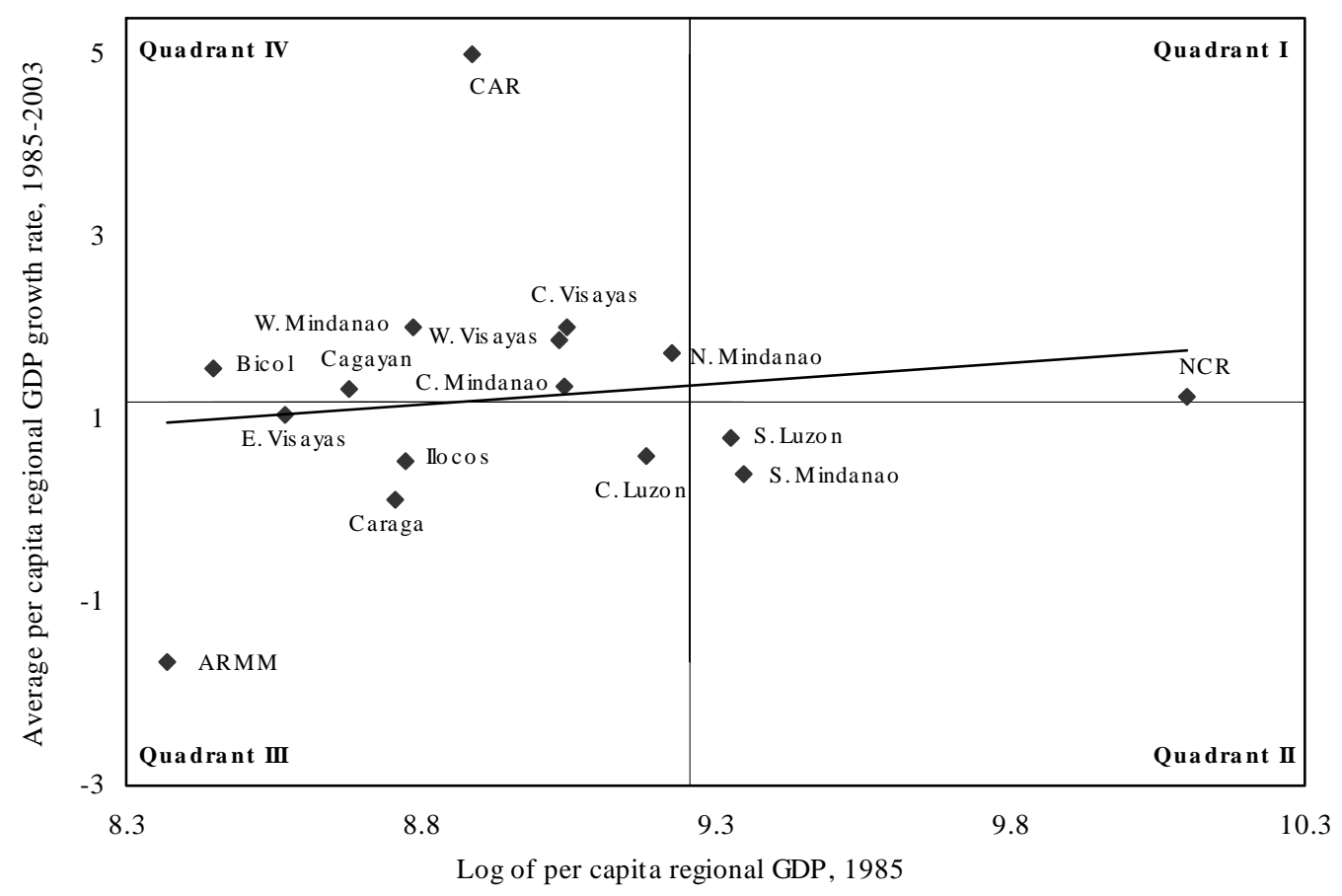

Note:

Regions are consistently defined across the period.

Source: Authors' estimates based on NSCB National Income Accounts, various years, andFamily

Income and Expenditure Survey, various years. 
Figure $4 \quad$ Philippines: Variation in Provincial Prices, 1985-2003

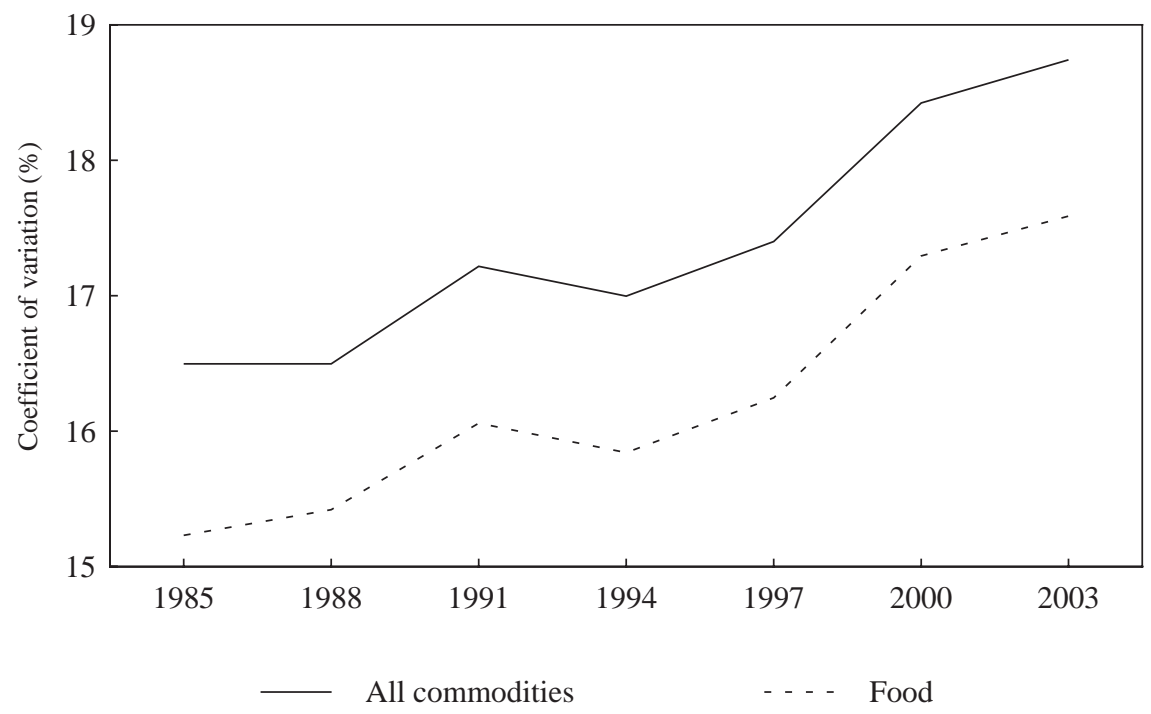

Note:

a Figures pertain to coefficients of variation of cost-of-living indices for a basket of goods and services.

Source: Balisacan (2001), updated to 2003 using the consumer price indices in the Philippine Statistical Yearbook. 
Figure 5 Regional Inequality in the PRC, Indonesia and the Philippines, 1975$2003^{\mathrm{a}}$

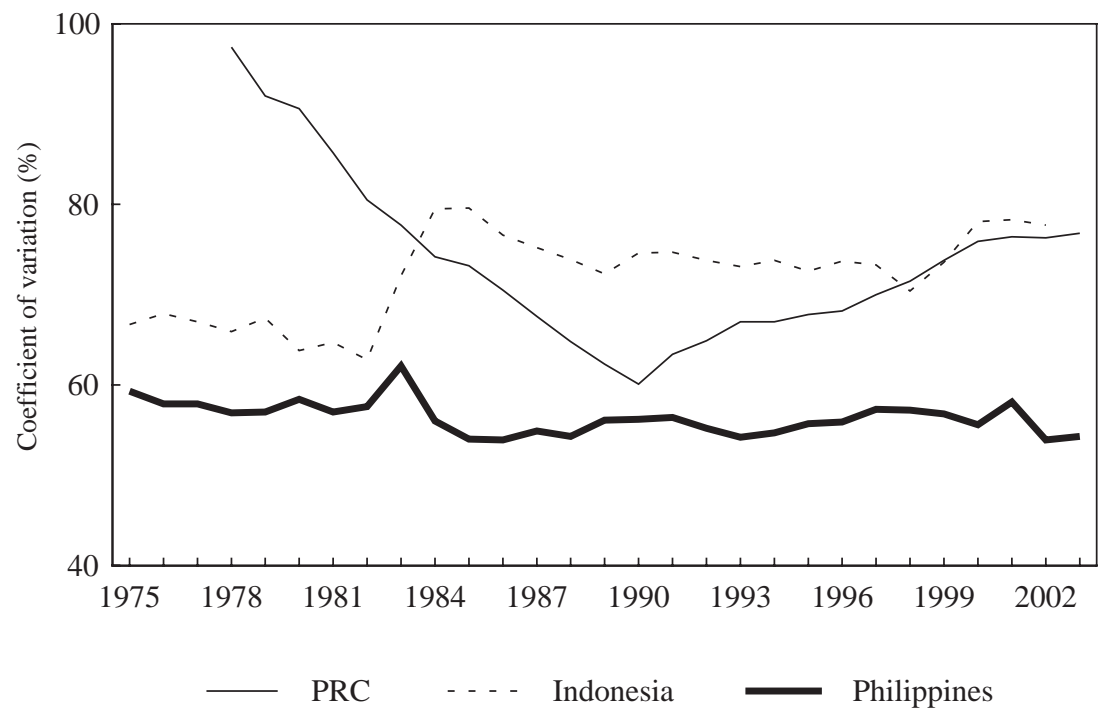

Note: Figures are coefficients of variation of real per capita regional incomes. In China and Indonesia, the regions referred to are the provinces. The Indonesia series excludes mining provinces.

Source: PRC: China Statistical Yearbook (various issues); Indonesia: Badan Pusat Statistik; Philippines: National Income Accounts. 
Page 27 of 33

Table 1 Philippines: Regional Growth and Structure, 1975-2003 (\%)

\begin{tabular}{|c|c|c|c|c|}
\hline$\overline{\text { Region }}$ & $1975-85$ & 1985-95 & 1995-2003 & 1975-2003 \\
\hline \multicolumn{5}{|c|}{$\begin{array}{l}\text { Average growth of regional } \\
\text { GDP (in } 1985 \text { prices) }\end{array}$} \\
\hline Philippines & 2.5 & 2.5 & 3.9 & 3.2 \\
\hline Luzon & 2.6 & 2.8 & 4.0 & 3.4 \\
\hline NCR & 2.4 & 2.8 & 4.3 & 3.4 \\
\hline $\begin{array}{l}\text { Central Luzon \& } \\
\text { Southern Tagalog }\end{array}$ & 2.6 & 3.1 & 3.6 & 3.4 \\
\hline Other Luzon & 3.0 & 2.3 & 4.3 & 3.4 \\
\hline Visayas & 2.4 & 2.1 & 4.0 & 3.2 \\
\hline Central Visayas & 2.7 & 2.6 & 4.8 & 3.7 \\
\hline Other Visayas & 2.3 & 1.7 & 3.4 & 2.8 \\
\hline Mindanao & 2.2 & 1.7 & 3.6 & 2.6 \\
\hline \multicolumn{5}{|c|}{ Share of national GDP } \\
\hline Luzon & 62.6 & 64.8 & 66.4 & 64.5 \\
\hline NCR & 28.8 & 31.6 & 34.4 & 31.5 \\
\hline $\begin{array}{l}\text { Central Luzon \& } \\
\text { Southern Tagalog }\end{array}$ & 23.3 & 23.2 & 21.9 & 22.8 \\
\hline Other Luzon & 10.5 & 10.0 & 10.1 & 10.2 \\
\hline Visayas & 16.7 & 16.3 & 15.8 & 16.2 \\
\hline Central Visayas & 6.4 & 6.5 & 6.7 & 6.5 \\
\hline Other Visayas & 10.3 & 9.8 & 9.1 & 9.7 \\
\hline Mindanao & 20.8 & 19.0 & 17.2 & 19.1 \\
\hline \multicolumn{5}{|c|}{ Share of total population } \\
\hline Luzon & 54.3 & 55.1 & 55.9 & 55.0 \\
\hline NCR & 12.3 & 13.2 & 13.1 & 12.8 \\
\hline $\begin{array}{l}\text { Central Luzon \& } \\
\text { Southern Tagalog }\end{array}$ & 22.8 & 23.9 & 25.7 & 24.0 \\
\hline Other Luzon & 19.2 & 18.0 & 17.1 & 18.2 \\
\hline Visayas & 23.2 & 21.4 & 20.3 & 21.7 \\
\hline Central Visayas & 7.9 & 7.5 & 7.4 & 7.6 \\
\hline Other Visayas & 15.3 & 13.9 & 12.9 & 14.1 \\
\hline Mindanao & 22.5 & 23.5 & 23.7 & 23.2 \\
\hline
\end{tabular}


Table 2 Philippines: Key Economic Indicators, 2003

\begin{tabular}{|c|c|c|c|c|c|}
\hline \multirow[t]{2}{*}{ Region } & \multirow{2}{*}{$\begin{array}{l}\text { Per Capita } \\
\text { GRDP } \\
\text { (index, } \\
\text { Philippines } \\
\text { =100) }\end{array}$} & \multicolumn{3}{|c|}{ Composition of GRDP (\%) } & \multirow{2}{*}{$\begin{array}{c}\text { GRDP } \\
\text {-Growth Rates } \\
\text { 1985-2003 } \\
\text { (\%) }\end{array}$} \\
\hline & & Agriculture $^{\mathrm{c}}$ & Industry & Services & \\
\hline Philippines & 100.0 & 15.0 & 31.8 & 53.2 & 3.1 \\
\hline NCR & 275.8 & - & 37.1 & 62.9 & 3.4 \\
\hline CAR & 129.9 & 11.0 & 56.5 & 32.5 & 6.4 \\
\hline Ilocos & 53.7 & 36.0 & 8.9 & 55.1 & 2.5 \\
\hline Cagayan Valley & 52.3 & 45.8 & 7.5 & 46.7 & 2.8 \\
\hline C. Luzon & 75.2 & 20.5 & 32.7 & 46.8 & 3.0 \\
\hline S. Tagalog & 85.7 & 20.2 & 37.5 & 42.3 & 3.5 \\
\hline Bicol & 43.3 & 22.7 & 16.1 & 61.2 & 2.2 \\
\hline W. Visayas & 83.5 & 22.6 & 25.7 & 51.7 & 2.9 \\
\hline C. Visayas & 93.4 & 10.4 & 27.9 & 61.7 & 3.7 \\
\hline E. Visayas & 50.5 & 29.9 & 25.7 & 44.4 & 2.0 \\
\hline W. Mindanao & 62.1 & 40.2 & 14.8 & 45.0 & 2.4 \\
\hline N. Mindanao & 101.8 & 28.6 & 30.2 & 41.2 & 2.7 \\
\hline S. Mindanao & 92.4 & 25.2 & 25.2 & 49.6 & 1.7 \\
\hline C. Mindanao & 76.6 & 40.2 & 28.0 & 31.8 & 3.4 \\
\hline ARMM & 23.2 & 48.6 & 10.3 & 41.1 & 2.5 \\
\hline Caraga & 47.8 & 38.0 & 18.0 & 44.0 & 2.1 \\
\hline
\end{tabular}

Notes:

GRDP=gross regional domestic product.

a Average per capita GDP for the Philippines in 2003 prices is P52,470. GRDP shares and growth rates are averages for three adjoining years (that is, the 1985 figure is the average for 1985-87 while the 2003 figure is the average for 2001-03). Regions are defined consistently across years. Provincial income shares from the household survey data were used.

Source: Authors' estimates based on NSCB, National Income Accounts, various years, and Family Income and Expenditure Survey, various years. 
Table 3 Philippines: Social Indicators, 2003

\begin{tabular}{|c|c|c|c|c|c|c|c|c|}
\hline \multirow[t]{2}{*}{ Region } & \multicolumn{2}{|c|}{ Poverty } & \multirow{2}{*}{$\begin{array}{l}\text { Income } \\
\text { Gini } \\
\text { Ratio }\end{array}$} & \multirow{2}{*}{$\begin{array}{l}\text { Life } \\
\text { Expectancy } \\
\text { at Birth }\end{array}$} & \multirow{2}{*}{$\begin{array}{c}\text { Adult } \\
\text { Functional } \\
\text { Literacy Rate }\end{array}$} & \multirow{2}{*}{$\begin{array}{c}\text { Primary \& } \\
\text { Secondary } \\
\text { Enrolment Rate }^{\mathrm{a}}\end{array}$} & \multicolumn{2}{|c|}{ Human Development Index } \\
\hline & Incidence & $\begin{array}{l}\text { Contribution } \\
\text { to total }\end{array}$ & & & & & 1990 & 2003 \\
\hline Philippines & 26.0 & 100.0 & 46.8 & 68.3 & 84.2 & 91.5 & 0.713 & 0.721 \\
\hline NCR & 4.9 & 2.6 & 43.3 & 70.0 & 94.6 & 92.3 & 0.944 & 0.804 \\
\hline CAR & 15.3 & 1.0 & 43.1 & 66.2 & 85.5 & 95.7 & - & 0.648 \\
\hline Ilocos & 16.9 & 3.4 & 41.2 & 69.5 & 88.4 & 91.6 & 0.592 & 0.649 \\
\hline Cagayan & 26.2 & 3.4 & 47.1 & 67.0 & 84.3 & 92.6 & 0.560 & 0.603 \\
\hline C. Luzon & 13.6 & 5.7 & 37.6 & 70.9 & 86.8 & 91.0 & 0.695 & 0.654 \\
\hline S. Tagalog & 20.8 & 13.0 & 43.7 & 68.9 & 88.7 & 92.7 & 0.654 & 0.646 \\
\hline Bicol & 45.7 & 10.7 & 48.9 & 68.6 & 79.8 & 90.7 & 0.488 & 0.538 \\
\hline W. Visayas & 26.7 & 7.8 & 46.6 & 68.3 & 81.5 & 93.9 & 0.527 & 0.601 \\
\hline C. Visayas & 36.6 & 10.4 & 47.3 & 70.7 & 81.6 & 90.3 & 0.528 & 0.592 \\
\hline E. Visayas & 45.0 & 8.2 & 49.2 & 65.6 & 76.5 & 90.1 & 0.473 & 0.520 \\
\hline W. Mindanao & 49.7 & 7.6 & 53.0 & 66.3 & 73.0 & 93.6 & 0.458 & 0.524 \\
\hline N. Mindanao & 29.8 & 4.1 & 48.1 & 68.6 & 82.6 & 90.1 & 0.531 & 0.610 \\
\hline S. Mindanao & 26.8 & 7.2 & 50.6 & 68.8 & 77.4 & 90.9 & 0.571 & 0.624 \\
\hline C. Mindanao & 34.1 & 4.2 & 46.2 & 66.5 & 80.0 & 93.1 & 0.479 & 0.551 \\
\hline ARMM & 63.4 & 7.2 & 40.1 & 54.2 & 65.9 & 80.3 & - & 0.370 \\
\hline Caraga & 36.9 & 3.7 & 44.5 & 64.8 & 80.5 & 92.9 & - & 0.531 \\
\hline
\end{tabular}

Notes: - = region did not exist in that year. a Estimates are for 2002.

Source: Authors' estimates based on Family and Income Expenditure Survey, 2003; Functional Literacy, Education and Mass Media Survey, 2003; Annual Poverty Indicators Survey, 2002; Philippine Human Development Report, various years. 
Page 30 of 33

Table 4 Philippines: Population and Migration, 2000

\begin{tabular}{lrrrrr}
\hline Region & $\begin{array}{c}\text { Total } \\
\text { Population } \\
\text { (thousand) }\end{array}$ & $\begin{array}{c}\text { Population } \\
\text { Density } \\
\text { (people/ } \\
\mathrm{km}^{2} \text { ) }\end{array}$ & \multicolumn{2}{c}{$\begin{array}{c}\text { Average Annual } \\
\text { Growth Rate }\end{array}$} & $\begin{array}{r}\text { Migration } \\
\text { Rate }^{\mathrm{b}}\end{array}$ \\
\cline { 5 - 6 } Philippines & $\mathbf{7 6 , 5 0 4}$ & $\mathbf{2 5 5}$ & $\mathbf{2 . 3}$ & $\mathbf{2 . 3}$ & $\mathbf{1 9 9 0 - 2 0 0 0}$ \\
NCR & 9,933 & 16,091 & 2.9 & 2.2 & -22 \\
CAR & 1,365 & 70 & 2.3 & 1.8 & -1 \\
Ilocos & 4,200 & 318 & 2.0 & 1.7 & -1 \\
Cagayan Valley & 2,813 & 90 & 2.0 & 1.8 & -5 \\
Central Luzon & 8,031 & 437 & 2.6 & 2.6 & 12 \\
Southern Tagalog & 11,794 & 239 & 3.0 & 3.6 & 26 \\
Bicol & 4,687 & 258 & 1.2 & 1.8 & -10 \\
Western Visayas & 6,211 & 301 & 1.8 & 1.4 & -6 \\
Central Visayas & 5,707 & 359 & 1.9 & 2.2 & 2 \\
Eastern Visayas & 3,610 & 155 & 0.9 & 1.7 & -6 \\
Western Mindanao & 3,091 & 161 & 2.2 & 2.3 & -9 \\
Northern Mindanao & 2,748 & 170 & 2.2 & 2.2 & 4 \\
Southern Mindanao & 5,189 & 183 & 3.0 & 2.6 & -1 \\
Central Mindanao & 2,598 & 144 & 3.3 & 2.5 & -9 \\
ARMM & 2,412 & 95 & 3.0 & 2.7 & -9 \\
Caraga & 2,095 & 98 & 2.5 & 1.7 & -6 \\
\hline
\end{tabular}

Notes:

a Calculations are based on intracountry migration.

b Net migrants, defined as in-migrants less out-migrants, per 1,000 population in 2000 .

Source: Authors’ estimates based on NSO, Census of Population and Housing, 1990 and 2000. 
Table 5 Philippines: Infrastructure Indicators, 2003

\begin{tabular}{lccccc}
\hline Region & $\begin{array}{c}\text { Road } \\
\text { Density } \\
\left(\mathrm{km} / \mathrm{km}^{2}\right)^{\mathrm{a}}\end{array}$ & $\begin{array}{c}\text { Access to } \\
\text { Potable } \\
\text { Water } \\
\text { (\% of }\end{array}$ & $\begin{array}{c}\text { Access to } \\
\text { Electricity(y) } \\
\text { \% of } \\
\text { households) }\end{array}$ & $\begin{array}{c}\text { Telephone } \\
\text { Line Density } \\
\text { (lines per } \\
100\end{array}$ & $\begin{array}{c}\text { Irrigation } \\
\text { Serviced } \\
(\%)^{\mathrm{b}}\end{array}$ \\
households) & \\
NCR & $\mathbf{0 . 2 6}$ & $\mathbf{7 9 . 4}$ & $\mathbf{7 7 . 1}$ & $\mathbf{8 . 1}$ & $\mathbf{4 4 . 7}$ \\
CAR & 5.72 & 84.6 & 99.1 & 25.8 & - \\
Ilocos & 0.15 & 82.2 & 72.1 & 6.3 & 74.1 \\
Cagayan Valley & 0.54 & 89.2 & 84.9 & 4.5 & 64.2 \\
Central Luzon & 0.19 & 83.3 & 74.5 & 1.0 & 42.4 \\
Southern Tagalog & 0.41 & 95.5 & 93.4 & 5.3 & 53.6 \\
Bicol & 0.21 & 85.0 & 85.1 & 8.7 & 49.2 \\
Western Visayas & 0.23 & 71.8 & 65.4 & 2.5 & 49.5 \\
Central Visayas & 0.34 & 69.4 & 69.0 & 6.2 & 38.9 \\
Eastern Visayas & 0.38 & 71.9 & 70.1 & 7.8 & 55.0 \\
Western Mindanao & 0.20 & 77.9 & 61.4 & 3.2 & 59.0 \\
Northern Mindanao & 0.22 & 58.9 & 52.6 & 1.0 & 46.9 \\
Southern Mindanao & 0.32 & 79.6 & 69.8 & 4.8 & 42.4 \\
Central Mindanao & 0.22 & 77.3 & 69.7 & 6.8 & 36.1 \\
ARMM & 0.19 & 72.0 & 56.5 & 2.9 & 26.9 \\
Caraga & 0.25 & 40.3 & 31.7 & 1.3 & 14.3 \\
\hline
\end{tabular}

Notes: a Road density is adjusted for quality (concrete equivalent).

b Irrigation serviced refers to the ratio of the total irrigated area to the potential irrigable area.

Source: Authors' estimates based on data from the Department of Public Works and Highways; NSO, Family Income and Expenditure Survey, 2003; NSCB, Philippine Statistical Yearbook, 2005. 
Figure 1: Map of the Philippines with 2005 Administrative Regions

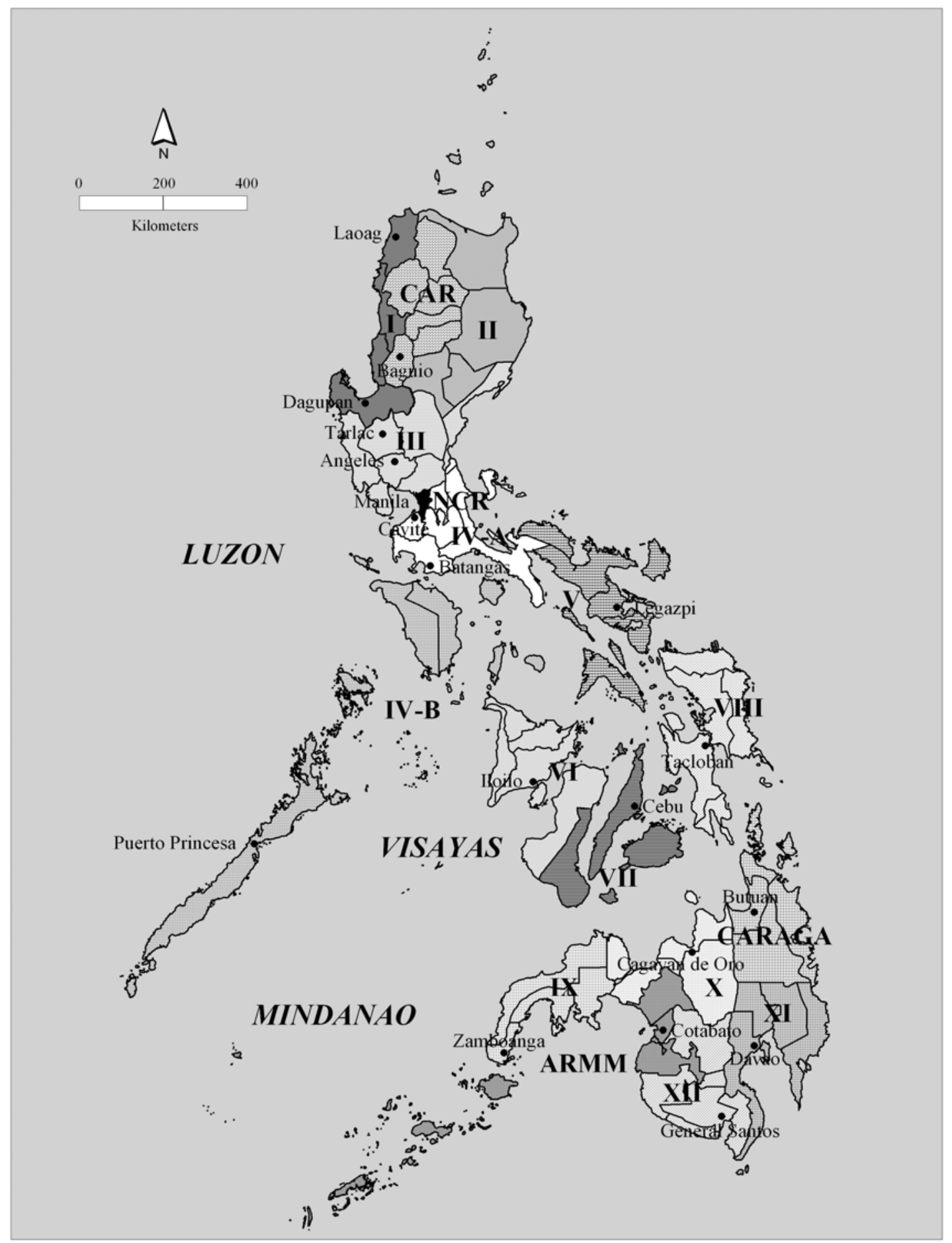




\section{3 regions}

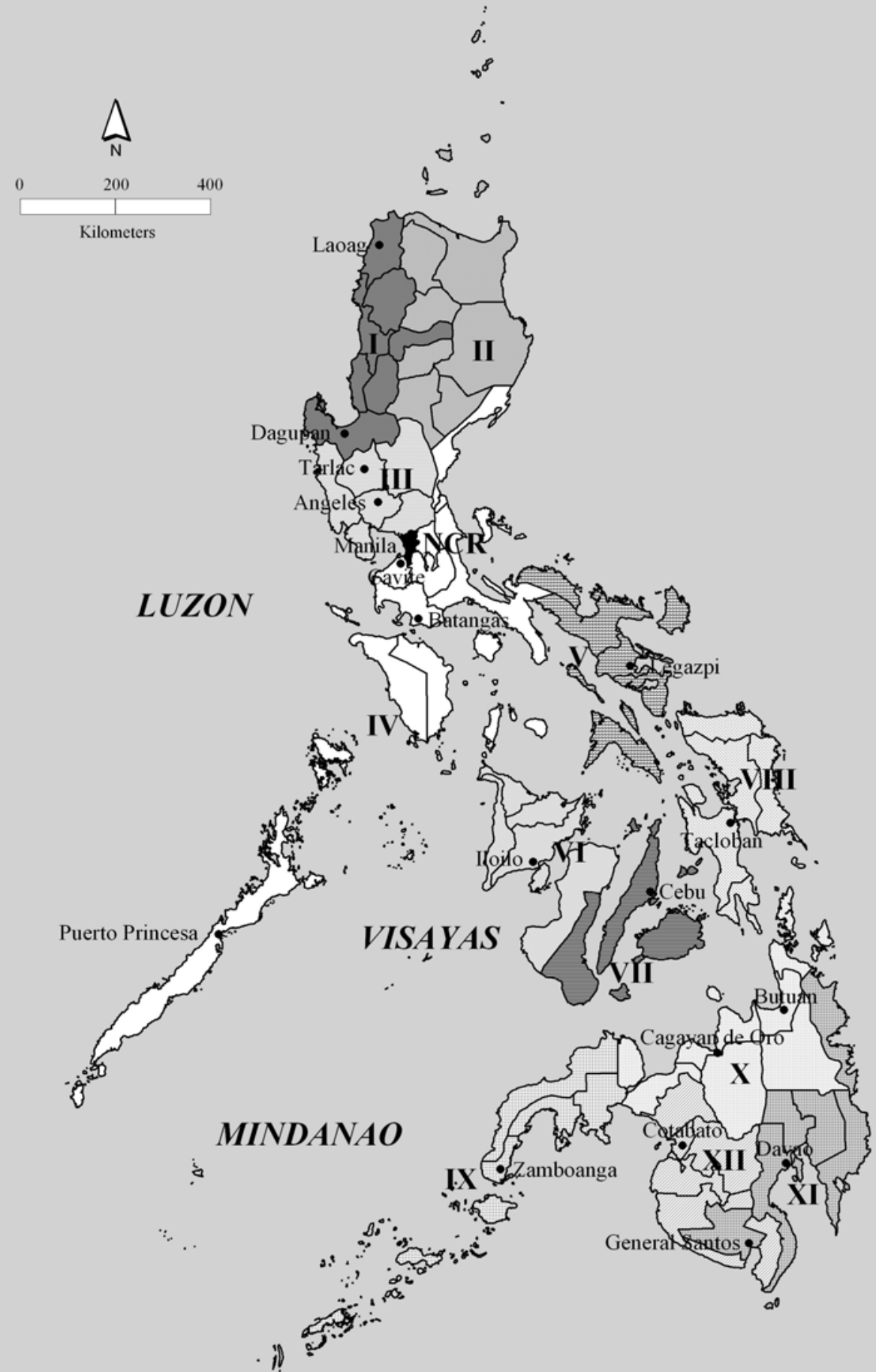

